\title{
THE
}

1984

\section{Towards a Lagrangian Description of the Gulf Stream}

\author{
Ping-Tung Shaw \\ University of Rhode Island \\ Hans Thomas Rossby \\ University of Rhode Island, trossby@uri.edu
}

Follow this and additional works at: https://digitalcommons.uri.edu/gsofacpubs

Terms of Use

All rights reserved under copyright.

\section{Citation/Publisher Attribution}

Shaw, P-T., \& Rossby, H. T. (1984). Towards a Lagrangian Description of the Gulf Stream. J. Phys. Oceanogr., 14(3), 528-540. doi: 10.1175/1520-0485(1984)0142.0.CO;2

Available at: https://doi.org/10.1175/1520-0485(1984)014<0528:TALDOT>2.0.C0;2

This Article is brought to you for free and open access by the Graduate School of Oceanography at DigitalCommons@URI. It has been accepted for inclusion in Graduate School of Oceanography Faculty Publications by an authorized administrator of DigitalCommons@URI. For more information, please contact digitalcommons-group@uri.edu. 


\title{
Towards a Lagrangian Description of the Gulf Stream
}

\author{
Ping-Tung Shaw and H. Thomas Rossby \\ Graduate School of Oceanography, University of Rhode Island, Kingston, RI 02881
}

(Manuscript received 9 May 1983, in final form 1 November 1983)

\begin{abstract}
Downstream velocity relative to the axis of the Gulf Stream is examined through the use of data from SOFAR floats. The speed calculated from the position of the floats along constant pressure surfaces is expressed in terms of a transformed cross-stream coordinate given by temperature, which is telemetered from the floats. The result is a distribution of downstream velocity unaffected by meanders from Cape Hatteras to $46^{\circ} \mathrm{W}$. The speed at $700 \mathrm{~m}$ is about $75 \mathrm{~cm} \mathrm{~s}^{-1}$ west of $57^{\circ} \mathrm{W}$ and decreases sharply to $40 \mathrm{~cm} \mathrm{~s}^{-1}$ to the east. In the deep water from 1300 to $2200 \mathrm{~m}$, the core speed is $35 \mathrm{~cm} \mathrm{~s}^{-1}$ between $65^{\circ}$ and $50^{\circ} \mathrm{W}$, if it is present. The flow in the Gulf Stream may be disturbed by local processes, which are frequently observed in satellite imagery. Examples are shingles, ring formation and meanders.

Although SOFAR floats are quasi-Lagrangian (isobaric) devices, the float data can give a Lagrangian description of the Gulf Stream. Above the main thermocline, a current coinciding with the tilting isotherms from Cape Hatteras to $46^{\circ} \mathrm{W}$ implies that water is efficiently transported downstream. In the deep ocean, water is accelerated by the surface Stream off Cape Hatteras and is at times transported downstream by the deep flow thus formed. The New England Seamounts can block this deep flow. There is little evidence of a deep current and thus, water transport east of the Seamounts.
\end{abstract}

\section{Introduction}

Until recently, studies of the Gulf Stream have emphasized the structure of its density field. Most information is obtained from hydrographic sections from one side of the Stream to the other. While there is uncertainty in the magnitude of water transported, these sections always reveal a set of uniformly sloping isopycnals extending from the surface to the bottom regardless of its meandering. The similarity of the density structure in these sections everywhere strongly suggests that the Gulf Stream is a simply-connected current over $3000 \mathrm{~km}$ from the Gulf of Mexico to Newfoundland. The continuity in the path of the Stream is supported by the studies of Hansen (1970) and Robinson et al. (1974). In such a picture, water properties change on a pressure surface across the Stream, and the Stream is a boundary separating the Slope Water and the Sargasso Sea Water. However, isopycnal water-mass analysis reveals that on the oxygen minimum layer $\left(\sigma_{\theta}=27.0\right)$, the Gulf Stream is no longer a property boundary (Rossby, 1982). This view is supported somewhat by the trajectories of a few quasi-Lagrangian (isobaric) SOFAR floats. In the main thermocline, the $700 \mathrm{~m}$ floats usually remain in the Stream over long distances (Rossby, 1982; Schmitz et al., 1981). However, floats at 1300 and $2000 \mathrm{~m}$ cross the Stream freely (Rossby, 1982).

The velocity structure provides another view of the Stream. The invariance in the slopes of density surfaces throughout the water column suggests considerable vertical coherence and horizontal continuity in the downstream velocity. Direct velocity measurements in the last decade, or so, generally reinforce the classic view of a vertically coherent velocity field in and above the main thermocline. The trajectories of surface drifters (Richardson, 1981) and SOFAR floats at 700 m (Rossby, 1982; Schmitz et al., 1981) generally show a vertically coherent current in the upper ocean. Observations in the deep water, however, seem to contradict the idea that the Stream is a unidirectional flow extending to the bottom. Deep moored current meter data averaged over a year or longer do not show mean eastward flow underneath the upper Stream (Luyten, 1977; Schmitz, 1977; Hendry, 1982). The above observations support the view that a current coincides with the density structure at shallow depths, but not in the deep waters. It is possible that the deep flow associated with the tilting density structure is limited both in space and time.

If the currents are parallel to the density structure, water parcels by definition must remain in the Stream. This Lagrangian property is important to the understanding of the transport of water masses by the Stream. The question of whether water parcels will remain in the Stream can be tested by either following the motion of Lagrangian particles or examining the velocity field in a coordinate system relative to the axis of the Stream, i.e., a natural coordinate system. We seek to use SOFAR floats to examine this question in a region between Cape Hatteras and $46^{\circ} \mathrm{W}$, where there is good coverage by SOFAR floats. Because of the limited 
number of floats in the Stream, no statistical analysis is made in this paper.

SOFAR floats are first treated as Lagrangian particles. This is true when disturbances in the Stream are weak. Floats move rapidly downstream over long distances with the current. Unfortunately, because of the isobaric property of SOFAR floats, their trajectories slowly deviate from the Lagrangian ones. This deviation is shown by the crossing of isopycnals or, approximately, isotherms in the Gulf Stream. The float trajectories are no longer representative of Lagrangian motion during certain strong disturbances.

Because floats cut across isotherms along an isobaric surface, the temperature telemetered by the floats is used to represent the float position relative to the tilting isotherms. The velocity of the floats can then be expressed in a distorted cross-stream coordinate. Analysis of the velocity field in such a way will result in a simple spatial distribution of currents across the Stream from Cape Hatteras to Newfoundland. The kinematics and energetics of the Stream that are derived are remarkably stable both in space and time.

Since SOFAR floats escape from the Stream in several cases, it is important to determine whether water parcels show the same behavior. Satellite infrared (IR) imagery can be used to identify the surface features of these processes. Examination of float trajectories contributes to a kinematic understanding of these processes and suggests pathways of water parcels.

The organization of this paper is as follows. Float trajectories are described in Section 2. Section 3 discusses the ability of SOFAR floats to follow the motion of water parcels. The velocity field in natural coordinates from Cape Hatteras to $46^{\circ} \mathrm{W}$ is analyzed in Section 4 . The disturbances in the Stream are examined in Section 5. From these results, we attempt to define the Gulf Stream in a Lagrangian sense and discuss the Lagrangian property of the Stream in various regions (Section 6).

\section{Float trajectories}

SOFAR floats are neutrally buoyant devices which follow approximately water motion in the ocean. When floats are located in the SOFAR channel such as between 700 and $2000 \mathrm{~m}$, they can be tracked more than $1500 \mathrm{~km}$ distance for over two years. The position of the floats is determined three times a day. In addition, most floats also measure temperature and pressure, which are averaged over two days along their trajectories. An overview of past SOFAR float studies has been given by Rossby (1982) and Rossby et al. (1983). In the present paper, we have used data from the reports by Spain et al. (1980) and O'Gara et al. (1982). The trajectories of Floats 31,73 and 74 have been discussed by Schmitz et al. (1981). Richardson et al. (1981) and Owens (1984) give a description of the floats launched along $55^{\circ} \mathrm{W}$ in 1980 . The complete dataset containing floats with numbers greater than 100 will appear in future data reports.

If a float moves rapidly downstream or there is a tight correlation between the float speed and temperature (see Section 4 for detailed discussion), the float is judged to be in the Gulf Stream. Figs. la and b summarize these trajectories at $700 \mathrm{~m}$ and between 1200 and $2200 \mathrm{~m}$ from Cape Hatteras to $46^{\circ} \mathrm{W}$. In these figures, we have truncated or excluded trajectories which were not related to the motion in the Gulf Stream. All floats in Fig. 1 were tracked three times a day except Float 31, which had only one fix each day. The larger dots in the trajectories represent days. Triangles are used to indicate the direction of motion every ten days. Trajectories with solid symbols and connecting lines are those in the Stream. The floats shown in Fig. 1 are listed in Table 1.

Despite a few escapes from the Stream, most 700 $m$ floats in Fig. 1a clearly follow the path of the Stream. Between Cape Hatteras and the New England Seamounts, Floats 21,26 and 59 were certainly in the Stream during the rapid downstream motion. The meandering of the Stream in this region was generally small. Over and to the east of the New England Seamounts, the trajectories showed a significant increase in meander amplitude. Float 21 made a northward loop of $200 \mathrm{~km}$ over the Seamounts. Float 120 turned northward after passing the Seamounts. It then oscillated in the north-south direction until reaching $55^{\circ} \mathrm{W}$. Between 55 and $49^{\circ} \mathrm{W}$, Floats 104, 105, 106 and 115 were following large-amplitude meanders in the path of the Stream.

The trajectories of the deep floats in Fig. $1 \mathrm{~b}$ were quite different from those at $700 \mathrm{~m}$. The cusps in the trajectory of Float 38 showed that it was in an eddy embedded in the Stream. The slow downstream drift of this eddy most likely indicated that the eddy was at the edge of the Stream. Float 39 was apparently in the Stream at $72^{\circ} \mathrm{W}$ with a maximum speed of $30 \mathrm{~cm}$ $\mathrm{s}^{-1}$. Deep floats were more likely to follow the Stream between $70^{\circ} \mathrm{W}$ and the New England Seamounts. Examples were Float 38 between 70 and $64^{\circ} \mathrm{W}$, and Floats 73 and 74 between 67 and $64^{\circ} \mathrm{W}$. Although meandering paths of the Stream were observed in several float trajectories east of $64^{\circ} \mathrm{W}$, two $2000 \mathrm{~m}$ floats crossed the Stream with no evidence of a Gulf Stream overhead: Float 154 moved north from the Sargasso Sea into the Slope Water at $64^{\circ} \mathrm{W}$, and Float 162 moved straight south from the Slope Water to the Sargasso Sea at $60^{\circ} \mathrm{W}$.

Localized disturbances were also present in the deep trajectories. The cyclonic loops at $38^{\circ} \mathrm{N}, 63^{\circ} \mathrm{W}$ and between 50 and $55^{\circ} \mathrm{W}$ in Fig. $1 \mathrm{~b}$ suggested that these deep floats were not able to follow the Stream locally. Curiously, there were no anticyclonic loops in Fig. $1 \mathrm{~b}$. Oscillatory motion below the main thermocline was present at $55^{\circ} \mathrm{W}$ in the trajectories of Floats 164 and 165 (Fig. 1b). 

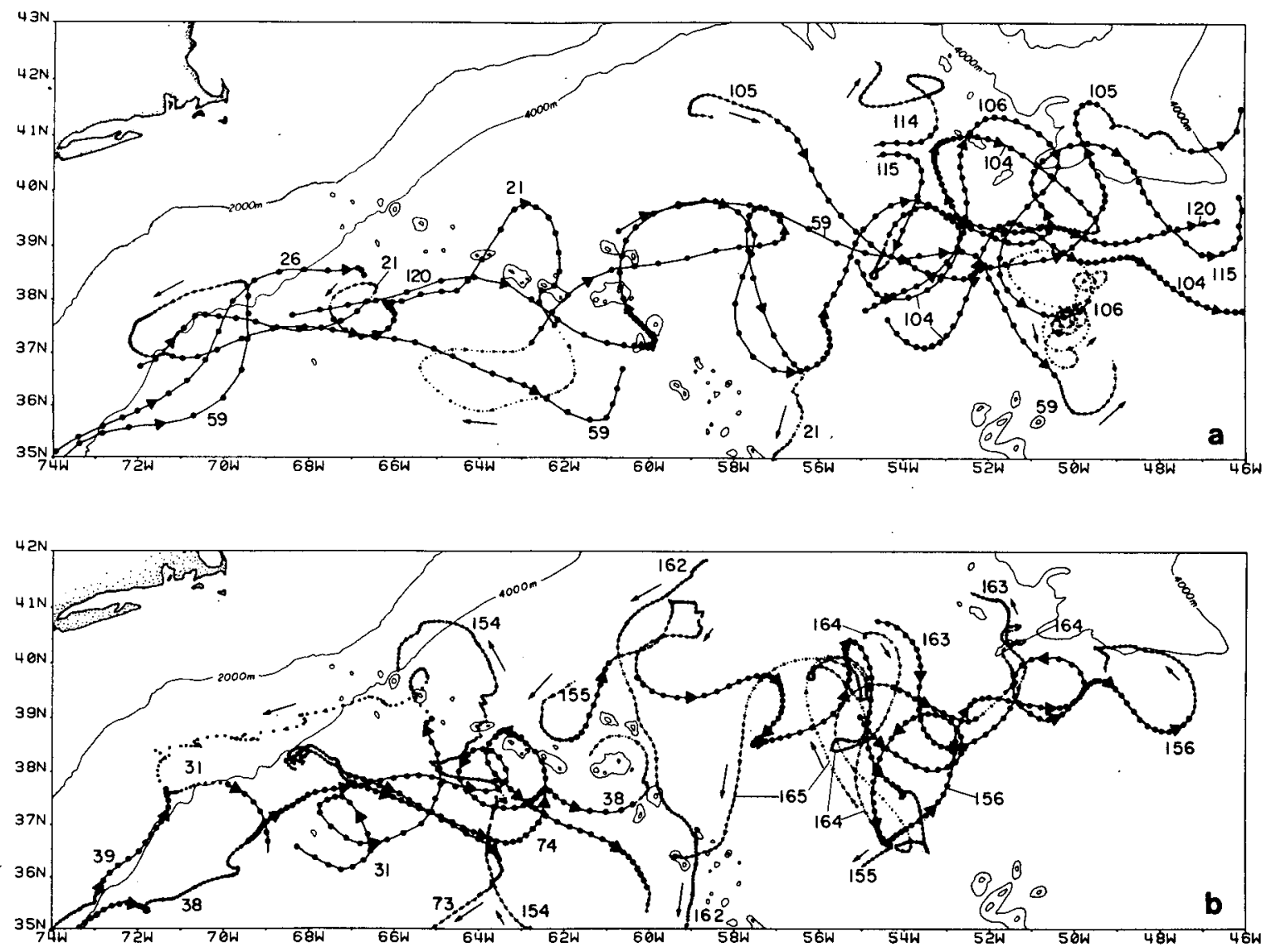

FIG. 1. Trajectories of SOFAR floats at depths: (a) $700 \mathrm{~m}$, (b) 1300-2200 m. Larger dots represent days. The direction of motion is indicated by triangles in the trajectories every ten days and by arrows next to the trajectories. Isobaths at 2000 and $4000 \mathrm{~m}$ are shown.

Besides following the path of the Stream, the 700 $\mathrm{m}$ floats in Fig. la could escape from the Stream. Floats 59 and 21 entered the Slope Water at 69 and $66^{\circ} \mathrm{W}$ respectively. Float 59 returned to the Stream after 45 days, while 21 reentered the Stream in 10 days. Float 114 moved into the Slope Water with an anticyclonic loop in the trajectory at $41^{\circ} \mathrm{N}, 53^{\circ} \mathrm{W}$. On the south side of the Stream, Float 21 was in the Sargasso Sea between 62 and $66^{\circ} \mathrm{W}$ for 25 days before it reentered the Stream. To the east of the New England Seamounts, the $700 \mathrm{~m}$ floats seemed to remain in the Sargasso Sea after they escaped from the Stream. Float 21 entered the Sargasso Sea at $56^{\circ} \mathrm{W}$. Floats 59 and 106 left the Stream at about $50^{\circ} \mathrm{W}$.

Deep floats escaped from the Stream more easily than the shallow ones. Floats 39 and 31 entered the Slope Water at 71 and $65^{\circ} \mathrm{W}$ respectively. For about 30 days, Float 155 was in the Slope Water region at $59^{\circ} \mathrm{W}$. Floats 163 and 164 entered the Slope Water at $52^{\circ} \mathrm{W}$. Several floats in the Stream moved into the Sargasso Sea. Float 73 left the Stream at $63^{\circ} \mathrm{W}, 74$ at $60^{\circ} \mathrm{W}$, and 155 at $54^{\circ} \mathrm{W}$. While $700 \mathrm{~m}$ floats seemed to enter the Sargasso Sea more frequently than the
Slope Water, deep floats escaped from the Stream both southward and northward.

The New England Seamounts have a profound effect on the trajectories of the SOFAR floats both at 700 $\mathrm{m}$ and below. At $700 \mathrm{~m}$, Float 21 followed a large meandering path at $63^{\circ} \mathrm{W}$ and Float 120 showed a wedge-shaped trajectory at $60^{\circ} \mathrm{W}$. At $1300 \mathrm{~m}$, the cyclonic motion of Float 38 over the Seamounts might be the result of an eddy breaking off the Stream. Furthermore, no deep floats west of the Seamounts crossed the Seamounts in Fig. $1 \mathrm{~b}$. The north-south motion of the two deep floats, 154 and 162, mentioned earlier also occurred in the vicinity of the Seamounts. Float 155 , originally in the Slope Water at $39^{\circ} \mathrm{N}, 62^{\circ} \mathrm{W}$, turned into the Stream when reaching the Seamounts. Besides their local effects, the New England Seamounts seem to block the deep flow, but, of course, not the surface flow.

Trajectories of SOFAR floats reflect the pattern of the Gulf Stream observed by Richardson (1981) in the trajectories of surface drifters. The escape of the floats at $700 \mathrm{~m}$ from the Stream into the Sargasso Sea is generally in the Gulf Stream recirculation region in- 
TABLE 1. Beginning and ending positions in the trajectories shown in Fig. I. Time is in Julian days.

\begin{tabular}{|c|c|c|c|c|c|c|c|}
\hline \multirow[b]{2}{*}{ Float } & \multirow{2}{*}{$\begin{array}{c}\text { Nominal } \\
\text { depth } \\
\text { (m) }\end{array}$} & \multicolumn{2}{|c|}{ From } & \multirow[b]{2}{*}{ Day/Year } & \multicolumn{2}{|c|}{ To } & \multirow[b]{2}{*}{ Day/Year } \\
\hline & & ${ }^{\circ} \mathrm{N}$ & ${ }^{\circ} \mathrm{W}$ & & ${ }^{\circ} \mathrm{N}$ & ${ }^{\circ} \mathrm{W}$ & \\
\hline
\end{tabular}

Shallow floats

$\begin{array}{rrrrrrrr}21 & 700 & 36.8 & 71.9 & 358 / 1980 & 35.0 & 57.1 & 121 / 1981 \\ 26 & 700 & 34.8 & 74.3 & 274 / 1978 & 38.5 & 66.7 & 293 / 1978 \\ 59 & 700 & 35.0 & 73.8 & 136 / 1979 & 36.7 & 60.6 & 217 / 1979 \\ 59 & 700 & 39.3 & 60.7 & 239 / 1979 & 36.8 & 49.0 & 280 / 1979 \\ 104 & 700 & 38.7 & 55.1 & 126 / 1980 & 39.4 & 50.7 & 177 / 1980 \\ 104 & 700 & 37.7 & 54.4 & 364 / 1980 & 37.9 & 45.9 & 44 / 1981 \\ 105 & 700 & 41.3 & 58.5 & 152 / 1980 & 41.5 & 46.1 & 262 / 1980 \\ 106 & 700 & 37.8 & 54.9 & 124 / 1980 & 37.1 & 50.0 & 237 / 1980 \\ 114 & 700 & 40.8 & 54.8 & 220 / 1981 & 42.3 & 54.6 & 278 / 1981 \\ 115 & 700 & 40.6 & 54.8 & 220 / 1981 & 39.9 & 46.1 & 306 / 1981 \\ 120 & 700 & 37.7 & 68.4 & 193 / 1981 & 39.5 & 46.6 & 292 / 1981\end{array}$

Deep floats

\begin{tabular}{rrrllllr}
31 & 1200 & 36.6 & 68.3 & $112 / 1978$ & 36.5 & 69.0 & $247 / 1978$ \\
38 & 1300 & 34.9 & 73.5 & $131 / 1979$ & 38.4 & 61.4 & $286 / 1979$ \\
39 & 1300 & 35.1 & 73.8 & $313 / 1978$ & 37.7 & 71.4 & $346 / 1978$ \\
73 & 1500 & 38.1 & $\mathbf{6 8 . 3}$ & $176 / 1979$ & 35.1 & 65.0 & $257 / 1979$ \\
74 & 2000 & 38.1 & 68.4 & $177 / 1979$ & 35.5 & 60.0 & $280 / 1979$ \\
154 & 2000 & 35.0 & 62.8 & $200 / 1981$ & 39.9 & 65.9 & $364 / 1981$ \\
155 & 2000 & 39.1 & 62.5 & $232 / 1980$ & 36.2 & 54.9 & $66 / 1981$ \\
156 & 2200 & 39.0 & 55.0 & $126 / 1980$ & 40.3 & 49.4 & $272 / 1980$ \\
162 & 2100 & 41.8 & 58.7 & $266 / 1981$ & 35.0 & 59.1 & $360 / 1981$ \\
163 & 2100 & 40.8 & 54.9 & $220 / 1981$ & 41.3 & 52.4 & $286 / 1981$ \\
164 & 1800 & 40.5 & 54.9 & $220 / 1981$ & 40.6 & 51.5 & $24 / 1982$ \\
165 & 2200 & 37.4 & 55.1 & $219 / 1981$ & 36.4 & 59.4 & $300 / 1981$ \\
\hline
\end{tabular}

dicated by surface drifters. The branching of the Stream south of the Grand Banks shown by surface drifters may cause the eastward motion (Floats 104, 115 and 120) and the southeastward motion (Floats 59 and $106)$ in the trajectories in Fig. 1a. Influence of the New England Seamounts on the surface path of the Stream was also observed in the trajectories of surface drifters. The SOFAR float trajectories suggest an anticyclonic gyre in the western North Atlantic proposed by Worthington (1976). However, a few shallow floats, which continue moving eastward to the southeast of Newfoundland, indicate possibly an intermittent current across the Newfoundland Ridge (see review by Fofonoff, 1981), a violation of Worthington's hypothesis (Clarke $e t$ al., 1980). This point is also made by Owens (1984).

The picture that emerges from the float trajectories is that floats at $700 \mathrm{~m}$ are likely to stay in the Stream over long distances, but not the deep floats. As we will show in the next section, SOFAR float trajectories are good approximations to the true Lagrangian motion except during processes where strong vertical motion is present. These float trajectories suggest that water parcels should follow the Stream above the main thermocline.

\section{Kinematic properties of SOFAR floats}

SOFAR floats are designed to follow pressure surfaces (Rossby et al., 1975). This property of SOFAR floats is accomplished by making their compressibility less than that of seawater. Consequently, the density of the floats will be different from that of the surrounding water if both are raised to a different pressure surface. Fig. 2 illustrates the motion of a SOFAR float in two types of displacement of density surfaces. The horizontal translation shown in Fig. 2a involves no pressure changes. Therefore, a float can follow the motion of water parcels and remain on the same isopycnal surface. In the case of vertical motion (Fig. 2b), water parcels move to a level with lower hydrostatic pressure. When following motion of water parcels upward, the float becomes denser than the surrounding water because the float is less compressible. Therefore, the float will remain near its original depth. The result is that the SOFAR float moves with the horizontal component of motion at the pressure surface and crosses isopycnal surfaces during isentropic motion.

We will consider the cross-stream motion during the escape of Float 59 from the Stream into the Slope Water at $38^{\circ} \mathrm{N}, 69^{\circ} \mathrm{W}$, in Fig. Ia (for a detailed map see Fig. 8). Fig. 3 shows the time series of the telemetered temperature and pressure from the float. Until day 143 , the float temperature was higher than $13^{\circ} \mathrm{C}$. The temperature then decreased rapidly to $5^{\circ} \mathrm{C}$ when it slipped out of the Stream between day 143 and day 147. For the next 40 days, Float 59 moved south-

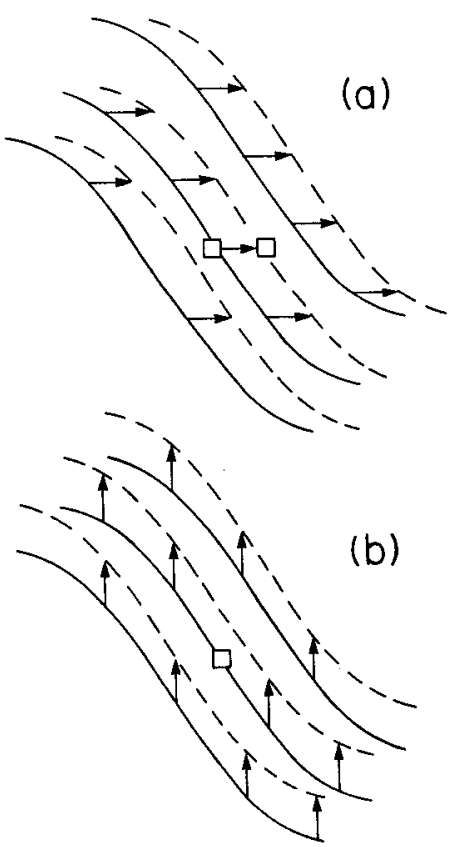

FIG. 2. Schematic diagram showing the motion of a SOFAR float (squares) in (a) a horizontal and (b) a vertical flow field. Arrows indicate displacement of isopycnals. 


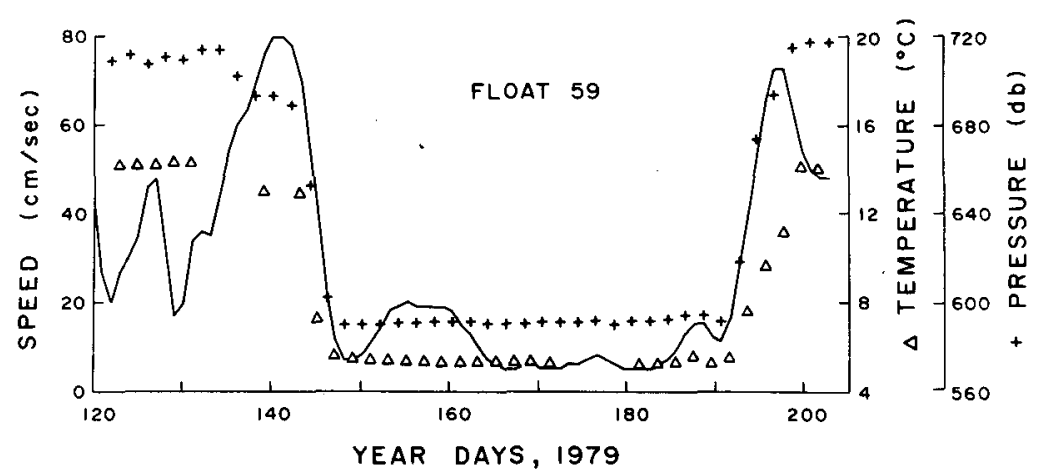

FIG. 3. Time series plot of speed (solid line), temperature (triangles), and pressure (crosses) from Float 59.

westward in the Slope Water. The float reentered the Stream at $37^{\circ} \mathrm{N}, 71.4^{\circ} \mathrm{W}$ on day 190 . By day 200 , the temperature had increased to $14^{\circ} \mathrm{C}$.

The location of Float 59 relative to the axis of the Stream is indicated by its temperature and pressure in a lateral section of isotherms across the Gulf Stream. Fig. 4 is a typical temperature section across the Stream from Rossby's PEGASUS observations off Cape Hatteras (Rossby, personal communication, 1983). The location of Float 59 in this plot is sketched by a shaded region at $700 \mathrm{~m}$ based on the data in Fig. 3. Because of the tight $T-S$ relationship in the Gulf Stream, these

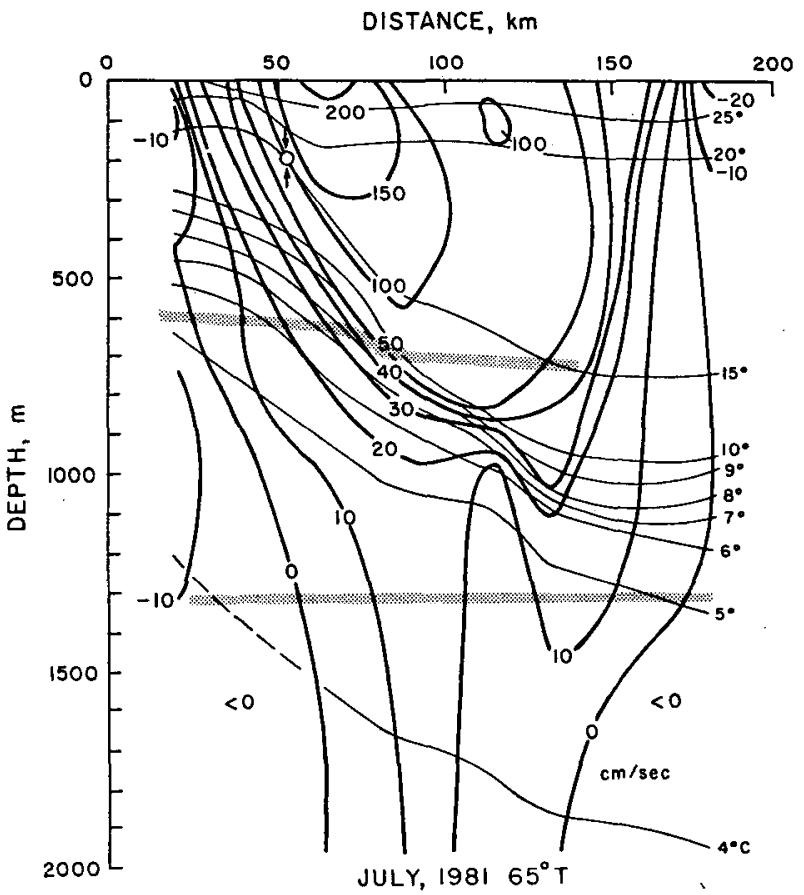

FIG. 4. Contour of downstream velocity in $\mathrm{cm} \mathrm{s}^{-1}$ (heavy lines) and temperature in ${ }^{\circ} \mathrm{C}$ (light lines) across the Gulf Stream from the PEGASUS section of July 1981 . The two shaded regions represent the depths of the floats which cross the Stream at 700 and $1300 \mathrm{~m}$ respectively. isotherms follow approximately isopycnals. During the cross-stream motion, the float undergoes an upward displacement of $120 \mathrm{db}$, which is about one-fifth the depth change of the $15^{\circ} \mathrm{C}$ isotherm across the Stream. SOFAR floats clearly move closer to isobaric surfaces than isopycnal surfaces.

This property of SOFAR floats is also mentioned by Rossby (1982), who described schematically the response of SOFAR floats to three types of isentropic motion in a baroclinic field. The two types of motion in Fig. 2a, b are the barotropic and baroclinic meandering respectively, in Rossby's paper. He also mentioned another type of motion where flow is along isopycnals, but this can be accomplished by a horizontal translation, together with a vertical displacement of density surfaces, i.e., a combination of the two modes just mentioned. The analysis of the motion in Fig. 2 shows that floats in this flow field will follow the horizontal velocity component and enter colder water when there is upwelling along sloping isopycnals. In the case of downwelling, the horizontal velocity is reversed and floats will enter warmer water.

When a float crosses isopycnals, variations in water density along the float trajectory prevent the float from being truly isobaric. This statement is supported by the correlation between the float pressure and the float temperature in Fig. 3. The large change in pressure of Float $59(120 \mathrm{db})$ indicates a large horizontal density difference across the Stream at $700 \mathrm{~m}$ (about $10^{\circ} \mathrm{C}$ difference in temperature in Fig. 4). Because of this upward displacement, the temperature measured by the float is not strictly on a constant pressure surface. However, the error is much smaller than the temperature difference across the Stream and the float temperature is a good approximation to the temperature at constant pressure. The corresponding motion of a $1300 \mathrm{~m}$ float (38) is also plotted in Fig. 4. The deviation from a constant pressure surface is less than $10 \mathrm{db}$ because of the smaller horizontal density variations. Since the width of the Stream is approximately independent of depth (Fig. 4), the vertical shear is ten times greater at $700 \mathrm{~m}$ than at $1300 \mathrm{~m}$. Thus, vertical 
motion in the Stream can disturb a $700 \mathrm{~m}$ float from true Lagrangian motion much more effectively than a $1300 \mathrm{~m}$ float. Consequently, the cross-stream motion of Float 59 does not necessarily imply the crossing of water parcels. In the deep waters, even though water parcels are still displaced some $600 \mathrm{~m}$ across the Stream, the trajectories of SOFAR floats and water parcels are much more similar.

\section{Velocity distribution along the Stream path}

When SOFAR floats move from the Sargasso Sea to the Slope Water along constant pressure surfaces as shown in Fig. 4, the temperature telemetered by the floats decreases monotonically. Therefore, temperature is a lateral coordinate relative to the axis of the Stream. Temperature sections perpendicular to the stream axis such as the one shown in Fig. 4 can translate the temperature coordinate into a lateral position. Unfortunately, temperature sections from hydrographic surveys often show large variations from a mean picture, perhaps because their orientation relative to the Stream axis is unknown. For these reasons; the discussion in this paper is restricted to the temperature coordinate. Nevertheless, a remarkably clear picture of the Stream with the effect of meanders removed emerges through the use of float temperature.
One application of the temperature coordinate is to derive the lateral distribution of speed in the Gulf Stream from SOFAR float data when the current coincides with the temperature structure. Fig. 3 shows the speed of Float 59 as it crossed the Stream. From day 138 to day 150 , the speed first increased to a maximum of $80 \mathrm{~cm} \mathrm{~s}^{-1}$ and then decreased to less than $20 \mathrm{~cm} \mathrm{~s}^{-1}$. This variation in speed results from the crossing of the float through the core of the current shown in Fig. 4. A plot of float speed versus telemetered temperature gives a velocity distribution in the Gulf Stream in a distorted lateral coordinate. In Fig. 5, we plot the lateral distribution of speed from four floats which crossed the Stream at various locations and depths. Fig. $5 \mathrm{a}$ is from the $700 \mathrm{~m}$ float 59 , which crossed the Stream between 73 and $67^{\circ} \mathrm{W}$. A maximum speed of $80 \mathrm{~cm} \mathrm{~s}^{-1}$ is reached in the core of the current. There is also a large temperature difference of $9^{\circ} \mathrm{C}$ across the Stream. To the east of $55^{\circ} \mathrm{W}$, the maximum speed at the same depth is only $40 \mathrm{~cm} \mathrm{~s}^{-1}$ as shown by the speed-temperature plot for Float 115, which crossed the stream between 55 and $47^{\circ} \mathrm{W}$ (Fig. 5b). The temperature range of $5^{\circ} \mathrm{C}$ across the Stream is also smaller. The corresponding curves at 1300 and $2000 \mathrm{~m}$ show weaker flow and of course much smaller temperature difference across the Stream. Fig. 5c is obtained from Float 38 at 1300 m west of the New
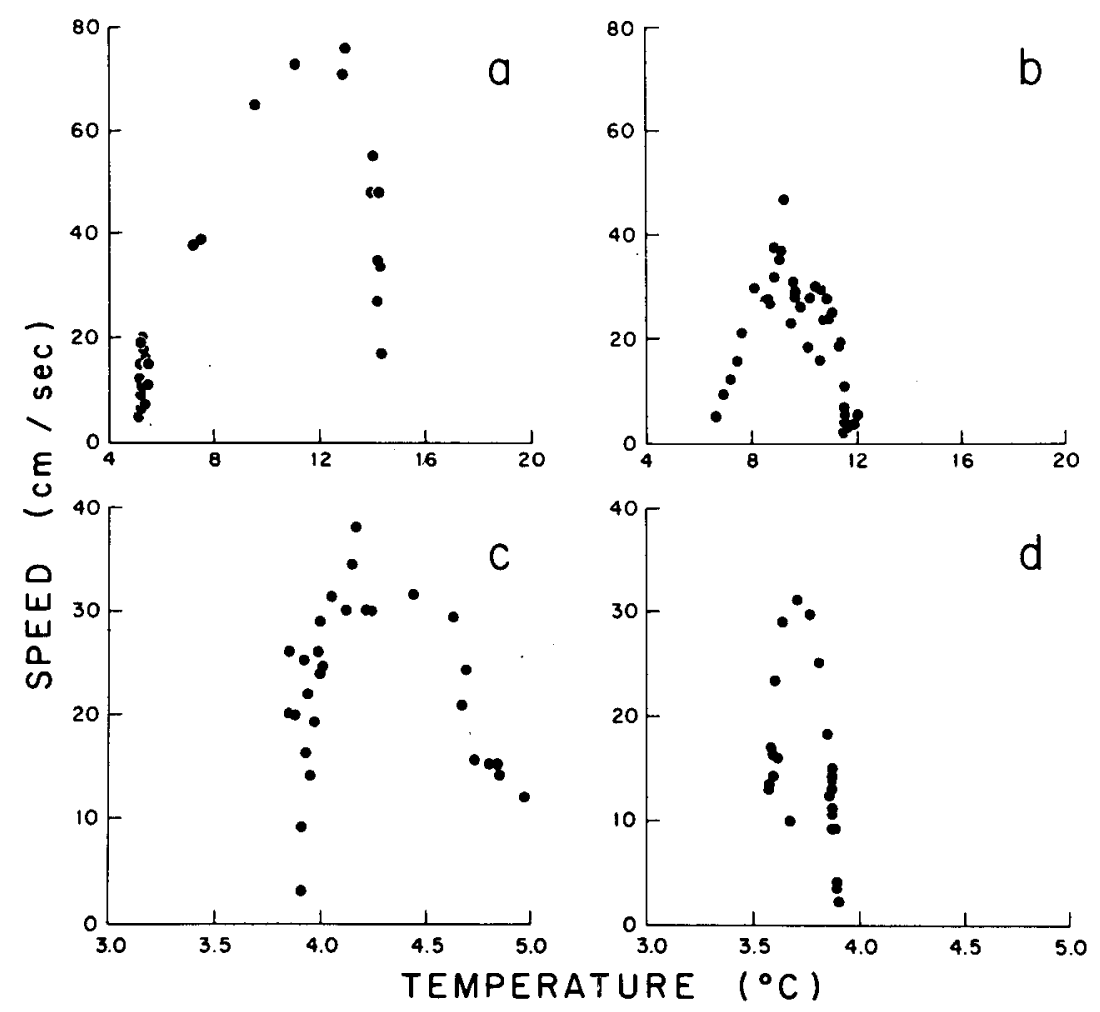

FIG. 5. Speed versus temperature plot for Floats (a) 59 at $700 \mathrm{~m}$ from day 117 to 202 in 1979 , (b) 115 at $700 \mathrm{~m}$ from day 236 to 316 in 1981 , (c) 38 at $1300 \mathrm{~m}$ from day 207 to 263 in 1979, (d) 155 at $2000 \mathrm{~m}$ from day 292 to 340 in 1980. 
England Seamounts between 66 and $61^{\circ} \mathrm{W}$. The speed is only slightly higher than that shown by the $2000 \mathrm{~m}$ float (155) to the east of the Seamounts at $60^{\circ} \mathrm{W}$ (Fig. 5d). The $2000 \mathrm{~m}$ float also reveals a smaller temperature range across the Stream than the $1300 \mathrm{~m}$ one.

A correlation curve between the speed of the floats and temperature can be found only when the floats are in the Stream. Data from $700 \mathrm{~m}$ floats in general have curves similar to the ones in Fig. 5. However, this relationship between speed and temperature does not exist for several deep floats such as Floats 154 and 162 , which show no evidence of a deep current. The speed-temperature curve of Float 38 in Fig. 5c no longer exists east of $62^{\circ} \mathrm{W}$, where the float was probably in a cold eddy. Table 2 summarizes the maximum speed and the time when there is a correlation between the speed and temperature of the floats.

A clear picture of the velocity distribution in the Gulf Stream emerges from the above analysis when there is a well-defined current. Fig. 6 is a plot of the data in Table 2. Because of the small difference in maximum speed for floats between 1300 and $2200 \mathrm{~m}$,

TABLE 2. Cross-stream motion with speed-temperature correlation in float trajectories. $U_{\max }$ is the maximum speed during crossing, and $\Delta T$ is the temperature difference across the Stream.

\begin{tabular}{|c|c|c|c|c|c|c|}
\hline Float & $\begin{array}{c}\text { Julian } \\
\text { day }\end{array}$ & Year & $\begin{array}{c}\text { Longitude } \\
\left({ }^{\circ} \mathrm{W}\right)\end{array}$ & $\begin{array}{l}\text { Depth } \\
\text { (m) }\end{array}$ & $\begin{array}{c}U_{\max } \\
\left(\mathrm{cm} \mathrm{s}^{-1}\right)\end{array}$ & $\begin{array}{r}\Delta T \\
\left({ }^{\circ} \mathrm{C}\right)\end{array}$ \\
\hline \multicolumn{7}{|c|}{ Shallow floats } \\
\hline $\begin{array}{r}21 \\
59 \\
26 \\
59 \\
21 \\
120 \\
21 \\
21 \\
59 \\
21 \\
120 \\
105 \\
115 \\
104 \\
104 \\
105 \\
115 \\
104\end{array}$ & $\begin{array}{r}360 \\
140 \\
284 \\
196 \\
1 \\
196 \\
38 \\
84 \\
241 \\
100 \\
235 \\
184 \\
228 \\
132 \\
164 \\
207 \\
298 \\
39\end{array}$ & $\begin{array}{l}1980 \\
1979 \\
1978 \\
1979 \\
1981 \\
1981 \\
1981 \\
1981 \\
1979 \\
1981 \\
1981 \\
1980 \\
1981 \\
1980 \\
1980 \\
1980 \\
1981 \\
1981\end{array}$ & $\begin{array}{l}71.2 \\
71.0 \\
70.0 \\
69.1 \\
68.7 \\
64.0 \\
63.5 \\
59.1 \\
58.7 \\
57.3 \\
57.1 \\
55.2 \\
53.8 \\
53.4 \\
50.5 \\
49.8 \\
47.3 \\
46.9\end{array}$ & $\begin{array}{l}700 \\
700 \\
700 \\
700 \\
700 \\
700 \\
700 \\
700 \\
700 \\
700 \\
700 \\
700 \\
700 \\
700 \\
700 \\
700 \\
700 \\
700\end{array}$ & $\begin{array}{l}52 \\
80 \\
76^{*} \\
73 \\
52 \\
80 \\
70 \\
67 \\
82 \\
72 \\
65 \\
49 \\
43 \\
45 \\
44 \\
43 \\
47 \\
24\end{array}$ & $\begin{array}{l}7.2 \\
9.3 \\
9.3 \\
7.2 \\
7.2 \\
7.2 \\
7.2 \\
9.3 \\
7.2 \\
7.2 \\
7.5 \\
5.0 \\
5.6 \\
5.6 \\
4.0 \\
5.0 \\
2.4\end{array}$ \\
\hline \multicolumn{7}{|c|}{ Deep floats } \\
\hline $\begin{array}{r}38 \\
73 \\
38 \\
155 \\
156 \\
156 \\
156 \\
156\end{array}$ & $\begin{array}{l}229 \\
226 \\
261 \\
310 \\
152 \\
132 \\
184 \\
209\end{array}$ & $\begin{array}{l}1979 \\
1979 \\
1979 \\
1980 \\
1980 \\
1980 \\
1980 \\
1980\end{array}$ & $\begin{array}{l}64.4 \\
64.3 \\
61.2 \\
59.0 \\
54.5 \\
54.0 \\
52.9 \\
50.6\end{array}$ & $\begin{array}{l}1300 \\
1500 \\
1300 \\
2000 \\
2200 \\
2200 \\
2200 \\
2200\end{array}$ & $\begin{array}{l}34 \\
34 \\
38 \\
31 \\
27 \\
28 \\
27 \\
32\end{array}$ & $\begin{array}{l}0.8 \\
0.7 \\
0.8 \\
0.3 \\
0.3 \\
0.3 \\
0.2 \\
0.2\end{array}$ \\
\hline
\end{tabular}

* No temperature data. Maximum speed estimated from speedpressure correlation.

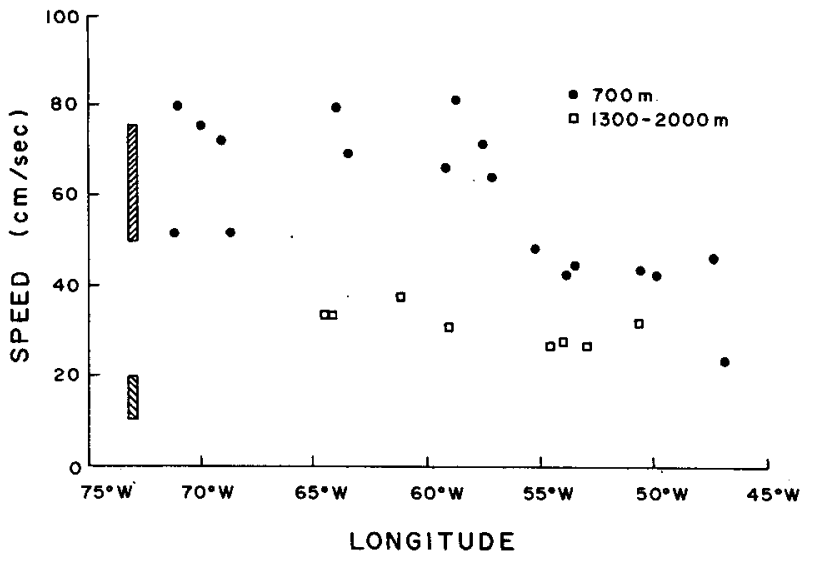

FIG. 6. Distribution of maximum speed in the Gulf Stream derived from SOFAR floats. The shaded regions at $73^{\circ} \mathrm{W}$ show the ranges of the maximum speed from the PEGASUS observations; the upper one is at $700 \mathrm{~m}$, and the lower one is between 1300 and $2200 \mathrm{~m}$. East of the New England Seamounts, only data from crossings which show speed-temperature correlation are shown.

no distinction is made between them. At $700 \mathrm{~m}$ the Stream shows two different current regimes. From Cape Hatteras to about $57^{\circ} \mathrm{W}$ the maximum speed in the Stream is about constant at $75 \mathrm{~cm} \mathrm{~s}^{-1}$. East of $57^{\circ} \mathrm{W}$ the speed decreases to $40 \mathrm{~cm} \mathrm{~s}^{-1}$. The two low values at 71 and $69^{\circ} \mathrm{W}$ are both from Float 21 . In the first case, the data were missing west of $72^{\circ} \mathrm{W}$. The float might cross the core of the Stream west of this longitude. In the second case, the float escaped from the Stream at a shingle-like structure. It is likely that the float did not reach the high-speed core of the Stream. Between 1300 and $2000 \mathrm{~m}$ the maximum speed is fairly constant at $30 \mathrm{~cm} \mathrm{~s}^{-1}$ from 65 to $50^{\circ} \mathrm{W}$. The sharp drop in the maximum speed at $700 \mathrm{~m}$ does not exist in the deep waters. Since Fig. 6 shows only the speed when the speed-temperature correlation exists, the speed given by the SOFAR floats should be regarded as an upper bound of the speed in the deep Gulf Stream. It is not surprising that the speeds at $55^{\circ} \mathrm{W}$ in Fig. 6 are several times higher than the mean values given by Owens (1984). In the latter case, the high float speed, which represents the speed of the meandering jet, is averaged out at fixed geographic locations.

Table 2 clearly shows an eastward decrease in the cross-stream temperature range from 9 to $5^{\circ} \mathrm{C}$ at 700 $\mathrm{m}$. This decrease agrees quite well with data from hydrographic sections across the Stream (e.g., Fuglister, 1963; Clarke et al., 1980). Below $1300 \mathrm{~m}$ the temperature contrast across the Stream is much smaller and, therefore, so is the vertical shear. Using a temperature difference of $0.8^{\circ} \mathrm{C}$ at $1300 \mathrm{~m}$ and a stream width of $50 \mathrm{~km}$, the velocity difference between 1300 and $2000 \mathrm{~m}$ is $\sim 15 \mathrm{~cm} \mathrm{~s}^{-1}$, which does not differ from the values in Fig. 5 .

The maximum velocity derived from the float data can be compared with the velocity from the PEGASUS 
experiments off Cape Hatteras from late 1979 to January 1983 (Rossby, personal communication, 1983). The two shaded regions at $73^{\circ} \mathrm{W}$ represent the ranges of the maximum speed at $700 \mathrm{~m}$ and that between 1300 and $2200 \mathrm{~m}$ respectively. The $700 \mathrm{~m}$ values are from 50 to $75 \mathrm{~cm} \mathrm{~s}^{-1}$, similar to the speed obtained by the SOFAR floats. However, the speed of 10-20 $\mathrm{cm} \mathrm{s}^{-1}$ between 1300 and $2200 \mathrm{~m}$ from the PEGASUS experiments is significantly lower than the speed of the deep floats in the Stream. The PEGASUS section is close to Cape Hatteras. It appears that the deep waters there have not yet been accelerated by the surface current.

The analysis in this section shows that currents coinciding with the density structure of the Stream can be found at $700 \mathrm{~m}$ from Cape Hatteras to $46^{\circ} \mathrm{W}$. Therefore, fluid parcels above the thermocline are likely to be advected downstream over long distances. In the deep waters, this current is limited both in space and time, and water parcels can escape from the Stream anywhere along its path.

\section{Perturbations in the Gulf Stream}

The well-defined current system discussed above is sometimes disturbed by local processes, as indicated by deviations from rapid downstream motion in the trajectories of Fig. 1. Satellite imagery, which is published weekly by the National Environment Satellite Data and Information Service, NOAA, is examined when available to determine if it is possible to relate these trajectory perturbations to events at the surface. These processes include lateral motion associated with shingles, rings, meanders and deep oscillations. Because of the paucity of information, the following discussion is somewhat more speculative.

\section{a. Ring formation}

The most effective way to exchange water is by the formation of cold- and warm-core rings. The surface pattern of the Stream from satellite imagery during the formation of a warm-core ring is overlaid on the trajectory of a $1200 \mathrm{~m}$ float (31) in Fig. 7. The float was apparently following the northward motion of a patch of warm water before day 150 in 1978. This warm patch became a large meander on day 155 and a ring was about to detach from the Stream on day 175. At the same time, the float escaped from the Stream with the ring and translated westward in the next 100 days. On the Sargasso Sea side, Float 106 escaped from the Stream southward at $38^{\circ} \mathrm{N}, 51^{\circ} \mathrm{W}$ (Fig. 1a) and it then moved in a cyclonic trajectory in the Sargasso Sea for about a year, clearly in a coldcore ring.

During the formation of rings, water is lost from the Stream. The rate of loss of fluid can be estimated as follows. Suppose ten rings are formed each year with a mean circumference of $500 \mathrm{~km}$ each. The total
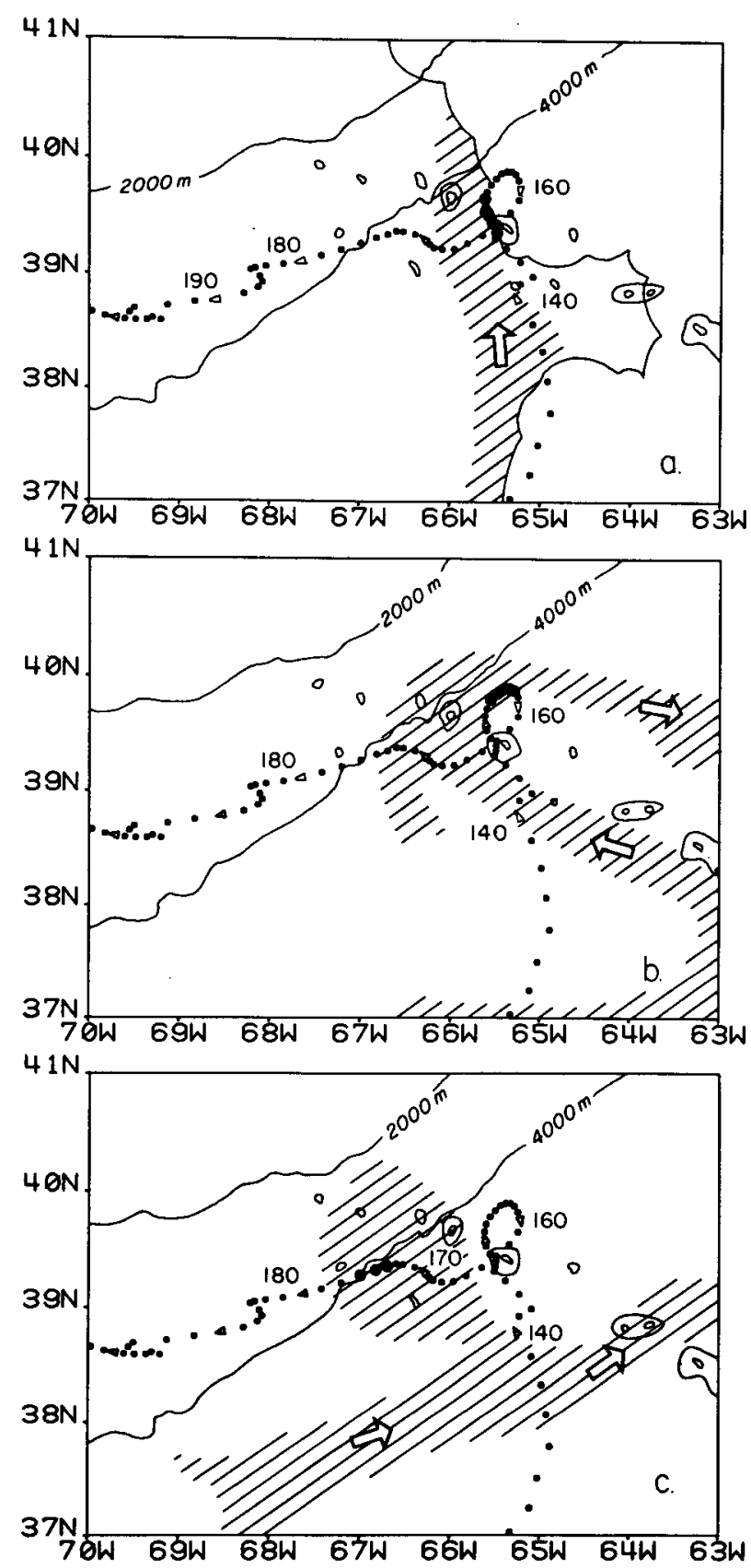

FiG. 7. Trajectory of Float 31 at $1200 \mathrm{~m}$. The shaded regions are the paths of the Gulf Stream shown in satellite imagery on days (a) 146-151, (b) 153-158 and (c) 175-177. The float locations at the time of imagery are marked by connecting solid circles. Arrows show the direction of surface flow in the Gulf Stream. Each number next to a triangle is the year day in 1978. Also shown are the 2000 and $4000 \mathrm{~m}$ isobaths.

length of the Stream being cut off is $5000 \mathrm{~km}$. A fluid parcel at $1 \mathrm{~m} \mathrm{~s}^{-1}$ will travel $30000 \mathrm{~km}$ in a year. Therefore, less than $20 \%$ of the water in the Stream is lost. This is true above the main thermocline. In the deep waters, current is much weaker and a large fraction of water will escape from the Stream. 


\section{b. Shingles}

Just north of the Gulf Stream, shallow segments of warm water may extend southwestward along the Gulf Stream, separated from the north wall by a band of cold water. Von Arx et al. (1955) used the term "shingles" to describe these features over the continental shelf south of Cape Hatteras. The cold band and warm filament (about $20 \mathrm{~m}$ deep) in a shingle are results of divergence at the surface. The divergence in turn is the consequence of upwelling from below (Lee $e t$ al., 1981). Similar features in the deep water may be related to the escape of SOFAR floats from the Stream to the Slope Water. Two cases were observed in the shallow trajectories: Float 21 at $38^{\circ} \mathrm{N}, 66^{\circ} \mathrm{W}$ and Float 59 at $38^{\circ} \mathrm{N}, 69^{\circ} \mathrm{W}$ (Fig. 1a). Fig. 8 shows a sequence of satellite IR images as Float 59 escaped from the Stream. The location of the escape corresponded well with the surface feature of a shingle. The escape of Float 59 into the Slope Water is not necessarily caused by nonisentropic motion in the Stream. It can be a result of upwelling along isopycnals (Section 3). If this is the case, shingles are the surface signature of a much deeper dynamic process extending to the main thermocline.

\section{c. Meanders}

The deceleration in the trajectory of Float 120 at $37^{\circ} \mathrm{N}, 60^{\circ} \mathrm{W}$, in Fig. 9, was due to southward meandering of the Stream. The trajectory of the float is shown together with the surface IR location of the Stream. From day 201 to day 205, Float 120 moved rapidly along the path of the Stream. The Stream meandered to the southeast on day 212 , and a cyclonic eddy formed. At the same time, both float speed and temperature decreased sharply, indicating that the float was in the Slope Water. The Stream entrained the float when the Stream meandered back. Note how the meander of the Stream and ring formation occurred over the New England Seamounts. The short absence of Float 120 from the Stream during the meandering of the Stream is probably the consequence of the quasiLagrangian property of SOFAR floats. We believe that the loss of fluid caused by meanders is small in shallow depths.

The deep floats behave differently from the shallow ones in response to meandering of the Stream. Several trajectories show closed, cyclonic loops in Fig. 1b. Examples are Float 38 at $64^{\circ} \mathrm{W}$, Float 74 at $63^{\circ} \mathrm{W}$ and Float 156 at 51 and $54^{\circ} \mathrm{W}$. The sequence of surface paths of the Stream associated with the loop in the trajectory of Float 38 is shown in Fig. 10. The trajectory coincided with the surface path of the Stream both before and after the crossover in the trajectory. The crossover occurred when the float was north of a southward meander. These examples show that the deep flow is poor in retaining fluid parcels.
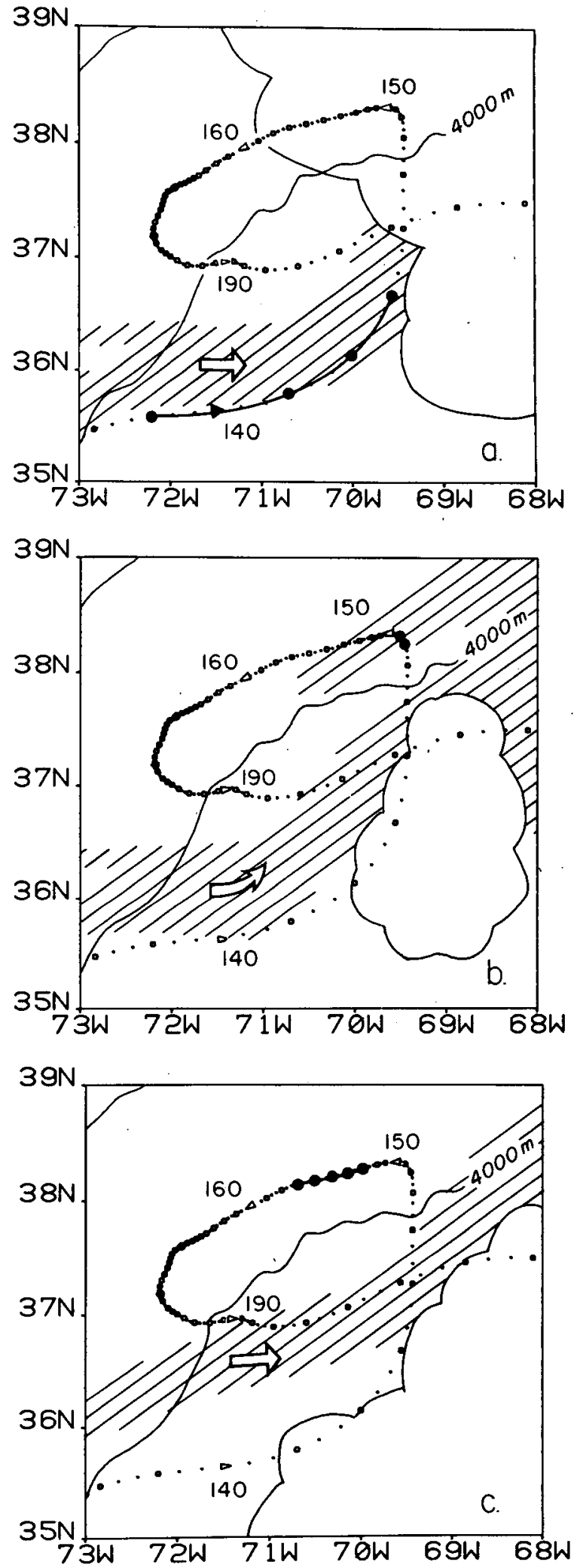

FIG. 8. As in Fig. 7 except for Float 59 at $700 \mathrm{~m}$ on year days (a) 139-143, (b) 147-150 and (c) 153-157 in 1979. Part of the map was covered by cloud. 


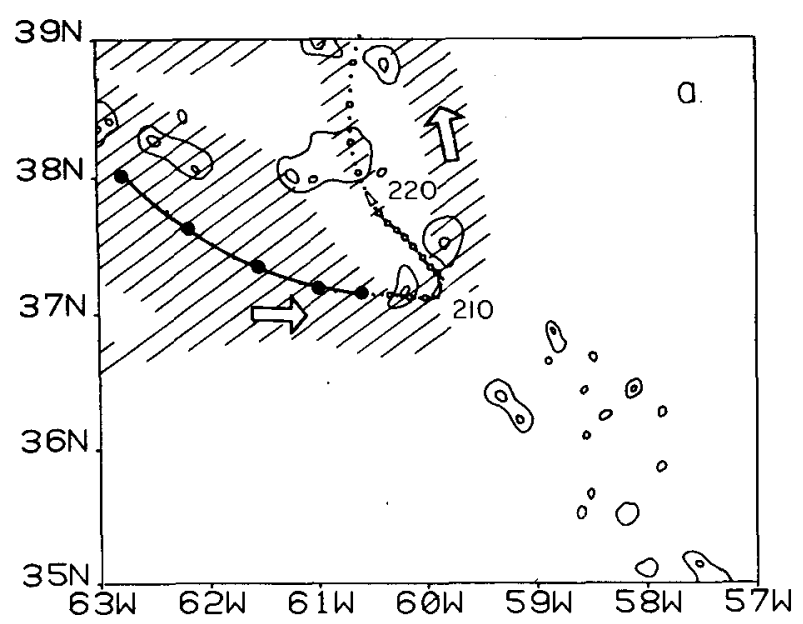

launched along $55^{\circ} \mathrm{W}$ around day 219 . The northernmost float (163) followed the path of the Stream after launch. One shallow float (115) and one deep float (164), deployed at about $30 \mathrm{~km}$ to the south of Float 163 , curved toward the southwest. Another deep float (165), which was at $37.3^{\circ} \mathrm{N}$ and $55^{\circ} \mathrm{W}$ on day 219 , moved northwestward. Floats 115,164 and 165 all made a $180^{\circ}$ turn at about day 250 . Float 115 was later entrained by the Stream at $39^{\circ} \mathrm{N}, 54.5^{\circ} \mathrm{W}$ on day 260 . Float 165 moved westward along $40^{\circ} \mathrm{N}$ after day 260 and eventually turned southward into the Sargasso Sea. Float 164 made one more turn at $39.7^{\circ} \mathrm{N}, 56.2^{\circ} \mathrm{W}$ on day 282. During that time, there was a slow eastward phase propagation of the surface expression of the Stream, as indicated by the IR position of the north-
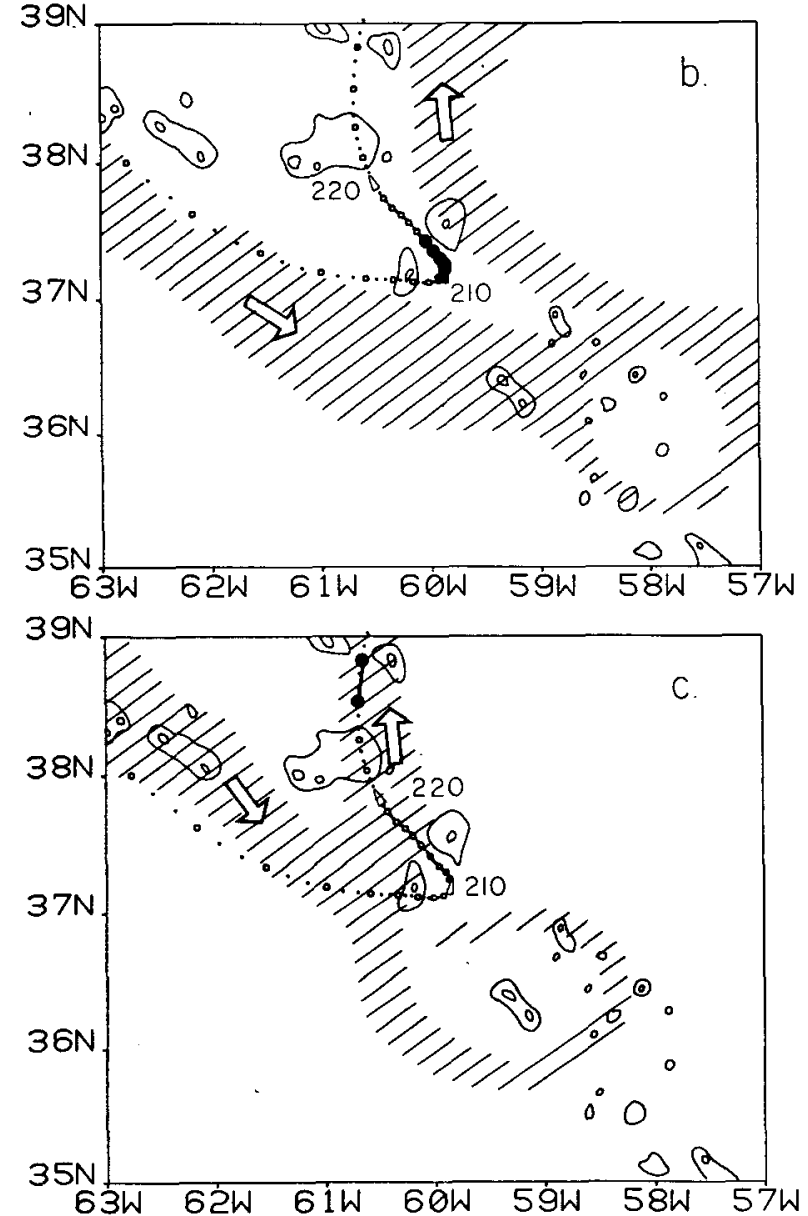

FIG. 9. As in Fig. 7 except for Float 120 at $700 \mathrm{~m}$ on year days (a) 203, (b) 212 and (c) 226 in 1981 .

\section{d. Oscillatory motion}

Coherent, oscillatory motion in the Gulf Stream is shown in Fig. 11 by the trajectories of one shallow $(700 \mathrm{~m})$ float $(115)$ and two deep $(2000 \mathrm{~m})$ floats $(164$ and 165). Floats $115,163(2000 \mathrm{~m}), 164$ and 165 were
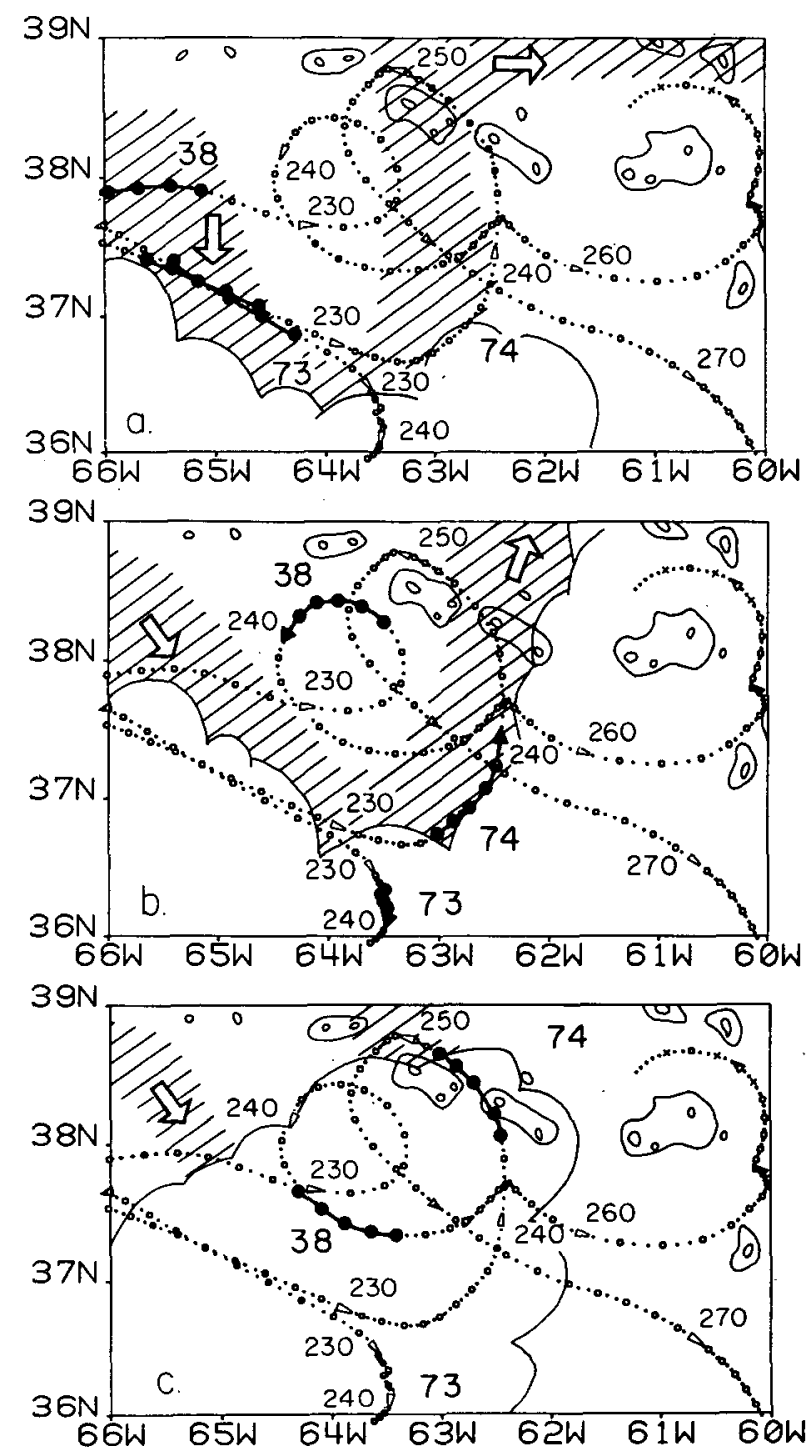

FIG. 10. As in Fig. 7 except for Floats $38(1300 \mathrm{~m}), 73(1500 \mathrm{~m})$ and $74(2000 \mathrm{~m}$ ) on year days (a) 223-227, (b) 235-240 and (c) 243-247 in 1979. 

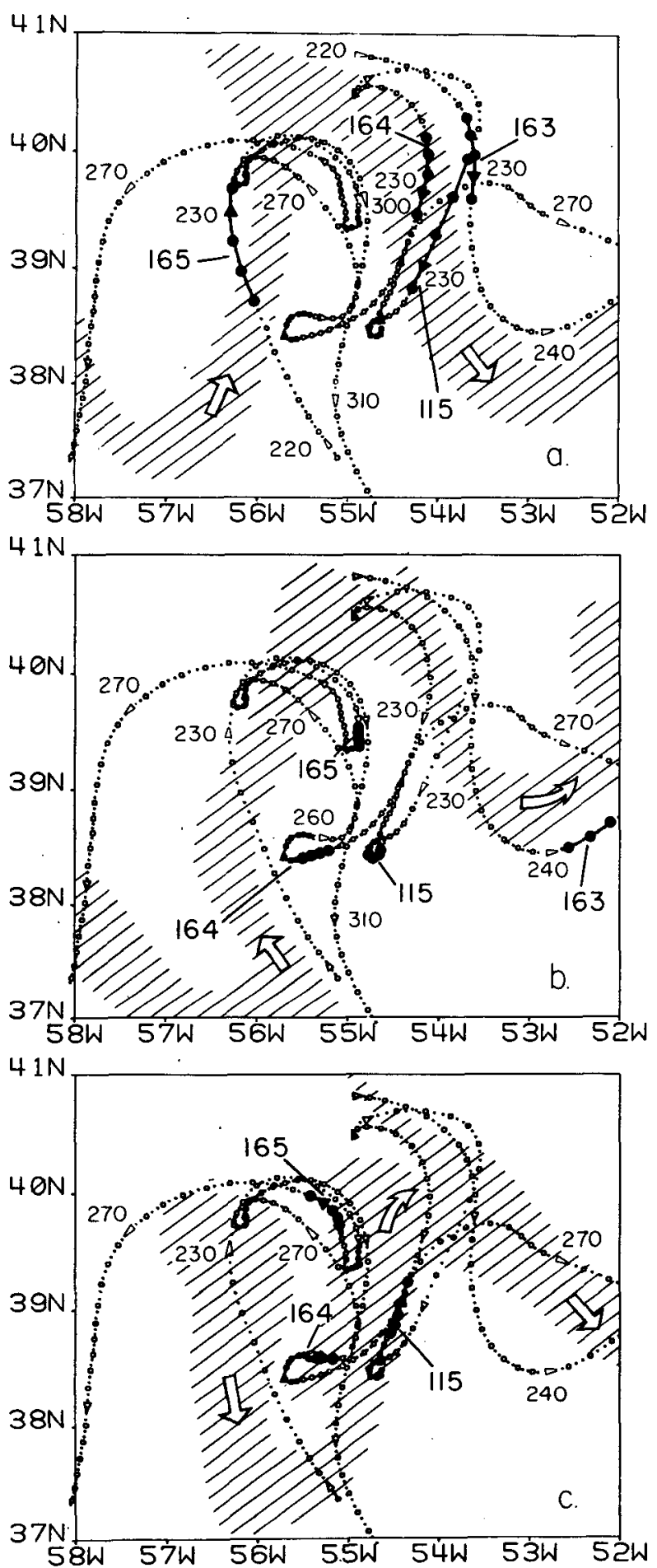

FiG. 11. As in Fig. 7 except for Floats $115(700 \mathrm{~m}), 163(2100$ $\mathrm{m}), 164(1800 \mathrm{~m})$ and $165(2200 \mathrm{~m})$ on year days (a) 229 , (b) 243 and (c) 259 in 1981 .

ward meander at $55^{\circ} \mathrm{W}$ in Fig. 11. As the meander propagated to the east, these floats (except Float 163) oscillated back and forth underneath the surface path of the Stream without much eastward displacement.
These oscillations in the Gulf Stream region clearly have a profound effect on the motion of water parcels below the thermocline. The deep trajectories provide compelling evidence for the nonexistence of coherent downstream flow underneath the shallow Gulf Stream.

\section{Discussion}

SOFAR float data generally show that a large percentage of water above the main thermocline will stay in the Stream over long distances. Based on these results, we introduce the concept of a Lagrangian Stream to represent this property of the shallow Stream. In a Lagrangian Stream, fluid parcels are advected along with the current over distances comparable to the downstream scale of the current, e.g., the wavelength of meanders. This definition emphasizes the discreteness of the Stream and its ability to contain the fluid it transports. It also implies a current impermeable to cross-stream exchange. This is not necessarily characteristic of atmospheric fronts, where the lateral circulation is much stronger than that in the ocean (Reiter, 1972). The natural coordinate system introduced by Robinson and Niiler (1967) presumed a strictly Lagrangian Gulf Stream.

SOFAR float data provide a description of the Lagrangian Stream above the thermocline. Fluid parcels can remain in the Stream from Cape Hatteras to as far east as $46^{\circ} \mathrm{W}$. The Stream is remarkably steady in speed both to the west and east of $57^{\circ} \mathrm{W}$. The decrease in speed suggests either broadening of the shallow Stream or loss of water because of recirculation. Although the New England Seamounts induce large-amplitude meandering of the shallow Stream, water parcels seem to be able to remain in the Stream. The disturbances such as shingles, ring formation and meanders may cause a small percentage of water to escape from the shallow Lagrangian Stream.

The deep flow is different. We do not think that a continuous Lagrangian Stream exists underneath the entire path of the shallow Stream. However, the speedtemperature correlation in some trajectories suggests that there is at times a tendency for a deep Lagrangian Stream to form west of the New England Seamounts. This tendency is indicated by the increase in speed from the PEGASUS sites $\left(\sim 73^{\circ} \mathrm{W}\right)$ to $67^{\circ} \mathrm{W}$. The acceleration in the deep waters may be induced by the shallow Stream after the Stream leaves the Blake Plateau and becomes a free jet. The New England Seamounts are a major barrier to deep flow. A deep current tends to form again, east of the Seamounts, as shown by the correlation between speed and temperature of the floats, but there are just as many trajectories showing no such correlation. The deep oscillation discussed earlier is an example. When there is a deep current, the similarity in the speed between the shallow flow and the deep flow east of $55^{\circ} \mathrm{W}$ indicates a tendency toward barotropic motion. 
Although there is no intention to have a detailed comparison of the above results with those from numerical models, it is interesting to describe similar features shown in simple numerical models, for example, the two-layer, flat-bottom, quasi-geostrophic models by Rhines (1977) and by Ikeda and Apel (1981). These two models will be referred to as $R$ and IA in this section. Rhines studied the evolution of an eastward-moving jet, perturbed by weak broadband noise, in an ocean with a constant Coriolis parameter. The jet was imposed as an initial condition in the surface layer with periodic boundary conditions. Consequently, the jet in $R$ was statistically uniform along its path, unlike the Gulf Stream, in which the meanders grow downstream. On the other hand, the jet in IA was fixed by boundary conditions and was more permanent than that in R. In IA, the perturbation was specified as an initial condition near the western wall, and the spatial growth of meanders in the jet was clearly shown. The beta effect was studied in IA, but it was primarily important to the detachment of eddies. Because of the different boundary conditions used, the time evolution of the jet in $\mathbf{R}$ has to be compared with the downstream evolution of the jet in IA.

These numerical models clearly describe the current and the density fields of the Gulf Stream. A continuous current associated with the density field above the thermocline is a consequence of quasi-geostrophic models. Besides the surface current, these models demonstrate formation of deep flow by the surface jet off Cape Hatteras. In R, a zonal mean abyssal flow in the same sense as the upper-layer stream is evident after 42 days. The same deep flow is shown in IA's Fig. 4 away from the western boundary. The vanishing of a continuous deep current in the numerical models occurs when the amplitude of meanders becomes large. At the same time, the flow field becomes more barotropic and is decoupled from the density field. Rhines pointed out that although the stream is still well-defined in the density field after 68 days, it almost vanishes in the deep velocity field. The same picture is shown in IA's Fig. 4, where the lower-layer jet is no longer continuous underneath the large meanders. However, the stream is still continuous in the interface height (IA's Fig. 5).

Except for the effect of the New England Seamounts, several features shown by the floats are demonstrated by the numerical models. West of the Seamounts, there is clearly a shallow Stream in the float trajectories. Moreover, the acceleration of the deep waters is demonstrated in the float data. To the east of $57^{\circ} \mathrm{W}$, the vanishing of the deep current and the tendency toward barotropic motion are also shown in both the model results and the observations from the floats.

\section{Summary}

The concept of a Lagrangian Gulf Stream is introduced in this paper to represent a current in which water parcels are carried over great distances without escaping from the Stream. Data from SOFAR floats indicate that a Lagrangian Stream may exist from Cape Hatteras to the southeast of Newfoundland in the main thermocline. The maximum speed in the shallow Stream decreases rapidly from $75 \mathrm{~cm} \mathrm{~s}^{-1}$ west of $57^{\circ} \mathrm{W}$ to $40 \mathrm{~cm} \mathrm{~s}^{-1}$ in $400 \mathrm{~km}$. This decrease in speed may suggest broadening of the Stream to the east and/or loss of water to the south. Underneath the thermocline, an intermittent deep Lagrangian Stream is formed at about $70^{\circ} \mathrm{W}$ by the acceleration of the shallow current. This deep current is interrupted by the New England Seamounts. Although several deep floats reveal speed and temperature correlation east of the Seamounts, a deep Lagrangian Stream probably is not established. Local processes may cause the escape of SOFAR floats from the Stream. Examples are formation of rings, shingling and meandering of the path. These processes may extend to the depth of the main thermocline and may cause upwelling or downwelling in the Stream. Despite these disturbances, most water in the Stream can be transported downstream above the main thermocline.

Acknowledgments. This work was supported by NSF Grant OCE-81-11498. We thank Ms. Renee O'Gara for processing the data. Some of the float data have been obtained in collaboration with the Woods Hole Oceanographic Institution SOFAR Float Group. Their cooperation is greatly appreciated.

\section{REFERENCES}

Clarke, R. A., H. W. Hill, R. F. Reiniger and B. A. Warren, 1980: Current system south and east of the Grand Banks of Newfoundland. J. Phys. Oceanogr., 10, 25-65.

Fofonoff, N. P., 1981: The Gulf Stream system. Evolution of Physical Oceanography, B. A. Warren and C. Wunsch, Eds., The MIT Press, 112-139.

Fuglister, F. C., 1963: Gulf Stream '60. Progress in Oceanography, Vol. 1, Pergamon, 265-373.

Hansen, D. V., 1970: Gulf Stream meanders between Cape Hatteras and the Grand Banks. Deep-Sea Res., 17, 495-511.

Hendry, R. M., 1982: On the structure of the deep Gulf Stream. $J$. Mar. Res., 40, 119-142.

Ikeda, M., and J. R. Apel, 1981: Mesoscale eddies detached from spatially growing meanders in an eastward-flowing oceanic jet using a two-layer quasi-geostrophic model. J. Phys. Oceanogr., 11, 1638-1661.

Lee, T. N., L. P. Atkinson and R. V. Legeckis, 1981: Detailed observations of a Gulf Stream spin-off eddy on the Georgia continental shelf, April 1977. Deep-Sea Res., 28, 347-378.

Luyten, J. R., 1977: Scales of motion in the deep Gulf Stream and across the continental rise. J. Mar. Res., 35, 49-74.

O'Gara, R. M., H. T. Rossby and D. L. Spain, 1982: SOFAR float pilot studies in the western North Atlantic 1975-1981. Data Rep. TR No. 82-3, University of Rhode Island, $160 \mathrm{pp}$.

Owens, W. B., 1984: A synoptic and statistical description of the Gulf Stream and subtropical gyre using SOFAR floats. J. Phys. Oceanogr., 14, 104-113.

Reiter, E. R., 1972: Atmospheric transport processes. Part 3: Hydrodynamic tracers. AEC Critical Review Series. USAEC Report TID-25731, 212 pp.

Rhines, P. B., 1977: The dynamics of unsteady currents. The Sea, Vol. 6, E. D. Goldberg, I. N. McCave, J. J. O'Brien and J. H. Steele, Eds., Wiley Interscience, 189-318. 
Richardson, P. L., 1981: Gulf Stream trajectories measured with free-drifting buoys. J. Phys. Oceanogr., 11, 999-1010.

- J. F. Price, W. B. Owens, W. J. Schmitz, H. T. Rossby, A. M. Bradley, J. R. Valdes and D. C: Webb, 1981: North Atlantic subtropical gyre: SOFAR floats tracked by moored listening stations. Science, 213, 435-437.

Robinson, A. R., and P. P. Niiler, 1967: The theory of free inertial currents. I. Path and structure. Tellus, 19, 269-291.

- J. R. Luyten and F. C. Fuglister, 1974. Transient Gulf Stream meandering. Part I: An observational experiment. J. Phys. Oceanogr., 4, 237-255.

Rossby, H. T., 1982: Eddies and the general circulation. Oceanography, the Present and Future, P. G. Brewer, Ed., SpringerVerlag, 137-161.

- A. D. Voorhis and D. Webb, 1975: A quasi-Lagrangian study of mid-ocean variability using long range SOFAR floats. J. Mar. Res., 33, 355-382.
- S. C. Riser and A. J. Mariano, 1983: The western North Atlantic-A Lagrangian viewpoint. Eddies in Marine Sciences, A. R. Robinson, Ed., Springer-Verlag, 66-91.

Schmitz, W. J., Jr., 1977: On the deep general circulation in the western North Atlantic. J. Mar. Res., 35, 21-28.

- J. F. Price, P. L. Richardson, W. B. Owens, D. C. Webb, R. E. Cheney and H. T. Rossby, 1981: A preliminary exploration of the Gulf Stream system with SOFAR floats. J. Phys. Oceanogr., 11, 1194-1204.

Spain, D. L., R. M. O'Gara and H. T. Rossby, 1980: SOFAR float data report of the POLYMODE Local Dynamics Experiment. TR No. 80-1, University of Rhode Island, 200 pp.

von Arx, W. S., D. F. Bumpus and W. S. Richardson, 1955: On the fine structure of the Gulf Stream front. Deep-Sea Res., 3, 4665.

Worthington, L. V., 1976: On the North Atlantic circulation. The Johns Hopkins Oceanographic Studies, No. 6, 110 pp. 